УДК 634.723.1: 54.021

\title{
СОСТАВ ПЛОДОВ И ЛИСТЬЕВ СМОРОДИНЫ ЧЕРНОЙ RIBES NIGRUM (ОБ3ОР)
}

\author{
() С.Н. Петрова", А.А. Кузнецова \\ Ивановский государственный химико-технологический университет, \\ Шереметевский пр-m, д.7, г. Иваново, 153000 (Россия), e-mail: laki@isuct.ru
}

\begin{abstract}
Приведен обзор сведений по химическому составу, биологической активности веществ черной смородины Ribes nigrum. Наличие в плодах и листьях черной смородины ценных биологически активных веществ определяет перспективность ее использования в качестве сырья для получения биологически активных добавок и пищевых красителей. Актуальной является селекционная работа по выведению новых сортов смородины черной, которая позволит расширить возможности перерабатывающих предприятий.

Ключевые слова: черная смородина, биологически активные вещества, фенольные соединения, антоцианы, антиоксидантная активность.
\end{abstract}

Смородина черная (Ribes nigrum) принадлежит к семейству Grossulariaceae, включает 150 видов и является одним из наиболее широко распространенных кустарников в мире. Родиной Ribes nigrum считается центральная и северная Европа, а также северная Азия: растения этого региона иногда выделяют в отдельный подвид - Ribes nigrum var. sibiricum или даже вид - Ribes cyathiforme. На Руси черная смородина известна с XI в. [1]. Название «смородина» происходит от старорусского слова «смород» - сильный запах. Английское обозначение смородины «currant» происходит от древнегреческого названия города Коринф и означает виноград, выращиваемый в этом регионе [2]. Изначально она применялась как целебное средство (в XV и XVII вв.). Позже на территории России этот кустарник стали возделывать в садах как ягодную культуру. Первое упоминание о черной смородине как о десертном плоде относится к 1671 г. [3].

Ribes nigrum относится к ягодным культурам, пользующимся заслуженным спросом, ее плоды обладают диетическими и лечебно-профилактическими свойствами. Согласно рекомендациям Института питания АМН, годовая норма потребления плодов, ягод и винограда должна составлять не менее 113 кг, в том числе ягод 14,4 кг, из них земляники и малины - по 3,8 кг, смородины черной - 4,5 кг, смородины белой и красной - 0,6 кг, крыжовника - 1,7 кг [4]. Смородина содержит комплекс значимых биологически активных веществ (БАВ) [5]. Состав ягод черной смородины представлен в таблице 1.

Из основных пищевых нутриентов в ягодах преобладают усвояемые углеводы. Среднее содержание суммы сахаров составляет от 6,6 до $15,4 \%$ в зависимости от сорта [5-7].

В составе сахаров больше фруктозы $(4,2 \%)$, меньше глюкозы $(1,5 \%)$ и сахарозы $(1,0 \%)$ [8]. Неусвояемые углеводы представлены клетчаткой (до $3 \%$ ) и пектинами (до 1,5\%) $[4,7,9,10]$. Высоким содержанием пектина характеризуются сорта Зеленая дымка, Черный жемчуг, Гулливер, Орловская серенада.

При созревании ягод суммарное содержание пектиновых веществ снижается и увеличивается сахаристость, что обусловлено действием пектиназы, катализирующей гидролиз пектиновых веществ до сахаров и накапливающейся в плодах по мере созревания [5, 12-14]. Важным свойством пектинов является их

Петрова Светлана Николаевна - доцент кафедры технологии пищевых продуктов и биотехнологии, кандидат химических наук, тел.: (4932)32-73-57 e-mail: laki@isuct.ru

Кузнецова Алена Андреевна - магистрант кафедры технологии пищевых продуктов и биотехнологии, e-mail: AlenaKuznec@yandex.ru способность адсорбировать бактериальные токсины, ионы тяжелых металлов, в том числе и радионуклиды; связывать и выводить из организма холестерины, предупреждая развитие атеросклероза [7]; предотвращать окисление аскорбиновой кислоты и катехинов в свежих плодах [10].

\footnotetext{
* Автор, с которым следует вести переписку.
} 
Таблица 1. Состав 100 г ягод черной смородины

\begin{tabular}{l|c|c}
\multicolumn{1}{c|}{ Компонент } & Содержание & $\begin{array}{c}\text { Источники } \\
\text { литературы }\end{array}$ \\
\hline Вода, г & $82,0-85,0$ & {$[8,9,11]$} \\
Белки, г & $1,0-1,4$ & {$[8,9,11]$} \\
Жиры, Г & $0,2-0,4$ & {$[9,11]$} \\
Углеводы, г & $6,6-15,4$ & {$[9,11]$} \\
Моно- и дисахариды, г & $6,7-13,7$ & {$[5,11]$} \\
Клетчатка, г & 3,0 & {$[8,9,11]$} \\
Крахмал, г & $0,6-2,7$ & {$[8,11]$} \\
Пектин, г & $0,38-1,5$ & {$[8,11]$} \\
Органические кислоты, г & $2,2-3,9$ & {$[8,11]$} \\
Зола, г & 0,9 & {$[8,11]$} \\
Витамин $\beta$-каротин, мг & $0,08-0,11$ & {$[5,12]$} \\
Витамин Е(токоферол), мг & 0,72 & {$[8,11]$} \\
Витамин В (тиамин), мг & 0,03 & {$[8,11]$} \\
Витамин В 2 (рибофлавин), мг & 0,04 & {$[8,11]$} \\
Витамин В6, мг & 0,13 & {$[8]$} \\
Витамин В (фолиевая кислота), мкг & 5,0 & {$[8,11]$} \\
Витамин РР (ниацин), мг & 0,3 & {$[8,11]$} \\
\hline
\end{tabular}

Сахара в сочетании с органическими кислотами и другими веществами обусловливают вкус плодов и ягод, их технологические особенности. Органические кислоты в плодах черной смородины в основном представлены лимонной $(2,0 \%)$, содержатся также яблочная $(0,25 \%)$ и щавелевая $(0,06 \%)$. Они благоприятно действуют на пищеварение, усиливают секрецию желез желудка и перистальтику кишечника. Органические кислоты являются катализаторами инверсии сахарозы в процессе хранения ягод [14].

Масло семян Ribes nigrum coдержит триглицериды, образованные с участием радикалов двух различных октадекатриеновых кислот: $\alpha$ - и $\gamma$-линоленовых (11-16\% от общей массы

жирных кислот), а также тетраеновой - стеаридоновой кислоты [5].

Плоды черной смородины богаты витаминами (табл. 1) [5-9, 11, 12]. В ягодах Ribes nigrum количество аскорбиновой кислоты в 3 раза больше, чем в апельсинах, и в 15-20 раз больше, чем в яблоках и грушах $[15,16]$. При этом она накапливается в гораздо большем количестве в плодах растений, произрастающих в регионах, где преобладает прохладный и влажный климат, что связано с накоплением в плодах большего количества антоцианов и проантоцианидинов, способных проявлять свойства «ловушки» солнечных лучей, превращая световую энергию в тепловую, и защищать растения от холода. Последние, имея относительно низкий окислительно-восстановительный потенциал, способны восстанавливать окисленную форму аскорбиновой кислоты. Так, в работе [15] показано, что проантоцианидины in vitro продлевают продолжительность полураспада витамина С на $400 \%$.

Листья черной смородины также содержат широкий комплекс биологически активных соединений (табл. 2). Максимальное количество витамина С накапливается в листьях к концу вегетативного периода. Имеются сведения, что содержание аскорбиновой кислоты в листьях по сравнению с ягодами больше в 1,2-2,3 раза, что обусловлено крайне низким содержанием в листьях ферментов, разрушающих аскорбиновую кислоту [17]. Содержание аскорбиновой кислоты в 100 г растительного сырья значительно превышает физиологическую норму суточной потребности человека в ней (90 мг/сутки) [18, 19$]$.

Ягоды черной смородины богаты полифенольными соединениями - от 488 до 1116 мг \%, которые значительно определяют их вкусовые, пищевые и лечебные достоинства. Содержание флавоноидов в ягодах - от 245 до 1047 мг \% [22]. По накоплению катехинов выделяют сорта Черный жемчуг, Муравушка, Привлекательная (420-489 мг \%) [23]. Суммарное количество флавонолов находится в пределах от 233,7 до 997,2 мг \% [10]. Более богаты указанными соединениями листья. Они содержат большее число компонентов флавонолов (до 9), но меньшее - фенолкарбоновых кислот (до 4) по сравнению с ягодами. В таблице 3 представлены средние данные по содержанию фенольных веществ в ягодах и листьях черной смородины [24].

По количественному содержанию в листьях черной смородины превалируют флаваны, среди которых преобладают конденсированные катехины (катехин и эпикатехин). Содержание их в листьях в 10-27 раз выше, чем в ягодах. Наибольшее количество конденсированных катехинов обнаружено в листьях сортов Лазурь (3279,9 мг \%), Оджебин $(3558,5)$, Багира $(3578,5)$ [10, 18$].$

Среди флавонолов, содержащихся в листьях, в количественном отношении преобладают гликозиды изокверцитрина, за ними следуют гликозиды кемпферола; мирицетин содержится в листьях в небольших

Таблица 2. Содержание аскорбиновой кислоты в листьях и ягодах смородины черной [7, 20, 21]

\begin{tabular}{l|c|c}
\hline Содержание аскорбиновой кислоты, мг \% & Ягоды & Листья \\
\hline Максимальное & 177 & 260 \\
Минимальное & 111 & 222 \\
Среднее & 144 & 245 \\
\hline
\end{tabular}
количествах [10, 25]. В листьях смородины содержится большое количество фенольных кислот (табл. 4). Среди полифенольных кислот доминирующей является хлорогеновая (0,81 мг \%) [26]. 
Таблица 3. Основные биофлавоноиды ягод и листьев черной смородины

\begin{tabular}{|c|c|c|c|c|c|c|}
\hline \multirow{2}{*}{ Содержание, мг \% } & \multicolumn{2}{|c|}{ Максимальное } & \multicolumn{2}{|c|}{ Минимальное } & \multicolumn{2}{|c|}{ Среднее } \\
\hline & ягоды & листья & ягоды & листья & ягоды & листья \\
\hline Флавонолы & 32 & 2700 & 7 & 234 & 18 & 697 \\
\hline Оксикоричные кислоты & 78 & 416 & 24 & 0 & 39 & 147 \\
\hline Биофлавоноиды & 468 & 7365 & 94 & 1952 & 301 & 4319 \\
\hline Флаваны: & & & & & & \\
\hline Свободные катехины & 101 & 941 & 12 & 117 & 61 & 446 \\
\hline Проантоцианидины & 198 & 2174 & 8 & 163 & 87 & 860 \\
\hline Конденсированные катехины & 179 & 4414 & 30 & 324 & 96 & 2169 \\
\hline
\end{tabular}

Особое внимание к черной смородине в последнее время связано с обнаружением благоприятного воздействия антоцианов плодов этого растения на зрительный аппарат человека, особенно для снятия утомления от длительной работы у дисплеев современных компьютеров [27]. Исследованиям, связанным с антоцианами плодов черной смородины, например, только в журнале «Journal of Agricultural and Food Chemistry» посвящено более 15 статей. Антоцианы являются пигментами клеточного сока и определяют

Таблица 4. Содержание фенольных кислот в листьях черной смородины [26]

\begin{tabular}{l|c}
\hline \multicolumn{1}{c|}{ Соединение } & Содержание, мг \% \\
\hline Салициловая кислота & 853,0 \\
Таниновая кислота & 836,6 \\
Галловая кислота & 113,2 \\
Кофейная кислота & 57,5 \\
транс-коричная кислота & 36,6 \\
Феруловая кислота & 19,5 \\
Паракумаровая кислота & 2,6 \\
\hline
\end{tabular}
окраску ягод, которая зависит от $\mathrm{pH}$ клеточного содержимого и потому может меняться при созревании плодов - процессе, сопровождающемся закислением клеточного содержимого. Усиленное образование антоцианов в клетках растения происходит при снижениях температур окружающей среды, при остановках синтеза хлорофилла. Поэтому больше всего их накапливают растения в местностях с суровыми климатическими условиями. Антоцианы поглощают свет в ультрафиолетовой и зеленой областях спектра. Поглощенная энергия частично превращается в тепловую, повышая на $1-4{ }^{\circ} \mathrm{C}$ температуру листьев [28]. Кроме того, антоцианы способны поглощать избыточные кванты света, защищая тем самым фотолабильные соединения, хлорофилл и наследственный аппарат клетки от повреждений [29, 30].

Антоциановый комплекс черной смородины определяется набором четырех главных компонентов: 3-глюкозидов и 3-рутинозидов дельфинидина и цианидина, который является неизменным для плодов всех сортов $R$. nigrum с черной окраской вне зависимости от сорта и региона выращивания. Соотношение между этими компонентами зависит от активности ферментов цепи метаболизма флавоноидов [7, 31, 32]. Антоцианами более богаты спелые плоды. В таблице 5 представлены данные антоцианового комплекса плодов черной смородины.

Антоцианы обладают капилляроукрепляющей активностью, антиоксидантным, антибактериальным, антиканцерогенным свойствами и эффективно применяются в медицине для лечения и предупреждения ряда заболеваний $[27,36,37]$. Наличие антиоксидантных свойств у антоцианов и их сродство к тканям глаза позволяет оказывать им положительное воздействие на глаза при различных зрительных и окислительных стрессах, способствуя запасанию глютатиона в глазах (вещества, определяющего антиоксидантную защиту тканей глаза) и предохраняя ткани глаза от повреждений, вызываемых свободными радикалами [38-40]. В модельных экспериментах было показано, что содержащиеся в черной смородине такие антоцианы, как цианидин-3-глюкозид и цианидин-3-рутинозид, способствуют регенерации родопсина [28], восстановление которого способствует усилению остроты зрения в сумерки [1, 28, 41, 42].

Антоцианы широко используются в пищевой промышленности в качестве красителей. Дельфинидины, содержащиеся в черной смородине, имеют более выраженный темный цвет и характеризуются высокой стабильностью, что обусловливает их востребованность [15]. Фирма «Натюрекс» производит натуральные антоциановые красители для молочных продуктов (йогурт, мороженое), напитков, джемов и конфитюров; разработана методика применения этих красителей для мясных продуктов [25].

Таблица 5. Антоциановый состав плодов черной смородины [22, 33-35]

\begin{tabular}{l|c|c|c|c}
\hline \multirow{2}{*}{ Содержание } & \multicolumn{3}{|c}{ Антоцианы, моль \%, } \\
\cline { 2 - 5 } & дельфинидин-3-глюкозид & дельфинидин-3-рутинозид & цианидин-3-глюкозид & цианидин-3-рутинозид \\
\hline Максимальное & 20,33 & 56,8 & 15,8 & 53,08 \\
Минимальное & 5,4 & 28,33 & 2,0 & 31,5 \\
Среднее & 13,2 & 39,11 & 6,45 & 36,3 \\
\hline
\end{tabular}


Имеются сведения по качественному и количественному минеральному составу плодов и листьев (табл. 6).

Ягоды черной смородины выделяются среди многих плодов и ягод высоким содержанием железа и калия. Учитывая нормы [18], следует отметить, что в листьях относительно высокое содержание магния, меди и марганца; в ягодах - молибдена, меди и марганца. Медь входит в состав ферментов, обладающих окислительно-восстановительной активностью и участвующих в метаболизме железа, стимулирует усвоение белков и углеводов. Марганец участвует в процессах обеспечения тканей организма человека кислородом; участвует в образовании костной и соединительной ткани, входит в состав ферментов, включающихся в метаболизм аминокислот, углеводов, катехоламинов; необходим для синтеза холестерина и нуклеотидов. Молибден является кофактором многих ферментов, обеспечивающих метаболизм серосодержащих аминокислот, пуринов и пиримидинов. Железо входит в состав различных по своей функции белков, в том числе ферментов; участвует в транспорте электронов, кислорода, обеспечивает протекание окислительно-восстановительных реакций и активацию перекисного окисления. Магний является кофактором многих ферментов, в том числе энергетического метаболизма, участвует в синтезе белков, нуклеиновых кислот, обладает стабилизирующим действием для мембран, необходим для поддержания гомеостаза кальция, калия и натрия.

Таблица 6. Содержание минеральных веществ в листьях и ягодах черной смородины [8, 43-45]

\begin{tabular}{l|c|c}
\hline \multirow{2}{*}{ Элемент } & \multicolumn{2}{|c}{ Содержание, мг \% } \\
\cline { 2 - 3 } Кальций & в листьях & в ягодах \\
Фосфор & 327 & 36 \\
Магний & 7,5 & 33 \\
Калий & 370 & 350 \\
Натрий & 158 & 32 \\
Железо & 2 & 1300 \\
Цинк & 0,5 & 130 \\
Медь & 0,75 & 130 \\
Марганец & 0,75 & 180 \\
Йод & 1,5 & 1 \\
Молибден & 0,0005 & 24 \\
\hline
\end{tabular}

В настоящее время ведется селекционная работа по выведению новых сортов, характеризующихся улучшенными хозяйственно-биологическими признаками и химическим составом. Их внедрение в производство является актуальным и позволит расширить возможности перерабатывающих предприятий для получения продуктов с высоким содержанием питательных и биологически активных веществ. Новые сорта черной смородины характеризуются большей урожайностью, повышенным содержанием биологически активных веществ, в том числе витамина С, Р-активных веществ, пектина, антоцианов; являются более крупноплодными и более выносливыми к вредителям и болезням [46-49].

Таким образом, черная смородина представляет интерес в качестве источника растительного сырья, содержащего ряд биологически активных соединений и обладающего высокой антиоксидантной активностью [50, 51]. Благодаря богатому химическому составу ягоды и листья Ribes nigrum могут служить прекрасным сырьем для пищевой, парфюмерной и фармацевтической промышленности.

\section{Список литературь}

1. Дейнека Л.А., Шапошник Е.И., Гостищев Д.А., Дейнека В.И., Сорокопудов В.Н. ВЭЖХ в контроле антоцианового состава плодов черной смородины // Сорбционные и хроматографические процессы. 2009. Т. 9, вып. 4. C. 529-536.

2. Brennan R.M., Janick J., Moore J.N. (Eds.) Currants and gooseberries // Fruit Breeding, Vol. II: Vine and Small Fruits Crops. John Wiley and Sons. Inc. New York, 1996. Pp. 191-295.

3. Barney D.L., Hummer K. E. Currants, gooseberries and jostaberries - a guide for growers, marketers and researchers in North America // Haworth Press. Binghamptom, NY., 2005.

4. Шапошник Е.И., Сорокопудов В.Н., Языкова В.В., Картушинский В.В., Трегубов А.В. Перспективные сорта черной смородины для использования в технологии изостатического прессования // Научные ведомости. Серия Естественные науки. 2010. №15(86). Вып. 12. С. 118-124.

5. Шапошник Е.И. Биологические и биохимические особенности плодов растений рода Ribes при интродукции в Белгородской области: автореф. дис. ... канд. биологических наук. Белгород, 2009. 200 с. 
6. Макаркина М.А., Янчук Т.В. Характеристика сортов смородины черной по содержанию сахаров и органических кислот // 165 лет ГНУ ВНИИСПК Россельхозакадемии. Современное садоводство. Генетика. Селекция. Сортоизучение. 2010. №2. С. 9-12.

7. Мясищева Н.В., Артемова Е.Н. Изучение биологически активных веществ ягод черной смородины в процессе хранения // Техника и технология пищевых производств. 2013. №3.

8. Позняковский В.М., Плотникова Т.В., Ларина Т.В., Елизарова Л.Г. Экспертиза свежих плодов и овощей. Качество и безопасность: учебно-справочное пособие. Новосибирск, 2005. 302 с.

9. Dale A. Potential for Ribes Cultivation in North America // HortTechnjlogy. 2000. Vol. 10, N3. Pp. 548-554.

10. Стрельцина С.А., Тихонова О.А. Питательные и биологически активные вещества ягод и листьев смородины черной (Ribis Nigrum L.) в условиях Северо-Запада России // Аграрная Россия. 2010. №1. С. 1-16.

11. Чернобровина А.Г. Ферментативный гидролизат черной смородины, его биохимическая характеристика и применение при получении пищевых продуктов: дис. ... канд. хим. наук. М., 2008. 211 с.

12. Балакирев Г.В. Полная энциклопедия. Лекарственные растения в народной медицине. М., 2006. 960 с.

13. Чуб В.В. Рост и развитие растений. М., 2003.

14. Казаков И.В. Оценка и создание исходного материала смородины черной для приоритетных направлений селекции // Современное состояние культур смородины и крыжовника: сб. научн. тр. Мичуринск, 2007. С. 81-90.

15. Жбанова Е.В. Изменчивость химического состава плодов черной смородины в разных регионах // Аграрная Россия. 2012. №1. С. 10-13.

16. Vagiri M. Black currant (Ribes nigrum L.) - An insight into the crop: A synopsis of a PhD study. Swedish University of Agricultural Sciences. 2012. 58 p.

17. Стукалов Н.В., Трунов Ю.В. Урожайность и витаминная ценность ягод смородины черной при использовании некорневых подкормок // Вестник МичГАУ. 2011. №1. Ч. 1. С. 38-41.

18. МР 2.3.1.2432-08. Нормы физиологических потребностей в энергии и пищевых веществах для различных групп населения Российской Федерации (утв. Роспотребнадзором 18.12.2008).

19. Давыдова В.Р., Выхованец Т.А. Технология пищевых продуктов со специальными свойствами // Новітні технології оздоровчих продуктів харчування XXI століття: Міжнародна науково-практична конференція. Харків, 2010. С. 225-226.

20. Тенгерекова Г.Г., Наквасина Е.И., Агаева О.П., Кузнецова О.В., Ляшевская Н.В. Динамика содержания аскорбиновой кислоты в смородине черной // Биоразнообразие, проблемы экологии Горного Алтая и сопредельных регионов: настоящее, прошлое, будущее: материалы междунар. конф. Горно-Алтайск, 2008. Ч. ІІ. С. 187-180.

21. Chrzanowski G., Sempruch C., Sprawka I. Investigation of phenolic acids in leaves of blackcurrant (ribes nigrum L.) and sour cherry (Prunus cerasus L.) // Electronic Journal of Polish Agricultural Universities. 2007. Vol.10. N4.

22. Макаров В.Н., Влазнева Л.Н., Жбанова Е.В., Денисова А.В., Абызов В.В., Гляделкина А.С., Зацепина И.В. Биологически активные вещества в ягодных культурах и продуктах их переработки // Хранение и переработка сельхозсырья. 2011. №2. С. 44-52.

23. Травникова Е.В. Смородина. М., 1996. 208 с.

24. Екимов А.А., Ломкова Е.А. Определение аскорбиновой кислоты в листьях смородины черной // Сборник тезисов научной конференции, посвященной 300-летию со дня рождения М.В. Ломоносова. СПб. 2011. С. 14-17.

25. Chrzanowski, G. C. Sempruch, I. Sprawka Investigation of phenolic acids in leaves of blackcurrant (Ribes Nigrum L.) and sour cherry (Prunus Cerasus L.) // Electronic Journal of Polish Agricultural Universities. 2007. N4. 6 p.

26. Макаревич А.М., Шутова А.Г., Спиридович Е.В., Решетников В.Н. Функции и свойства антоцианов растительного сырья // Центральный ботанический сад НАН Беларуси. Минск, 2010. Т. 4. Вып. 2. 11 с.

27. Nakaishi H., Matsumoto H., Tominaga S., Hirayama M. Effect of black currant anthocyaniside intake on dark adaptation and VDT work-induced transient refractive alteration in healthy humans // Altern. Med. Rev. 2000. Vol. 5. Pp. 553-562.

28. Novruzov E.N. Pigments of the reproductive organs of plants and their value. Baku, 2010. 308 p.

29. Matsumoto H., Nakamura Y., Tachibanaki S., Kawamura S., Hirayama M. Stimulatory effect of cyanidin 3-glycosides on the regeneration of rhodopsin // J. Agric. Food Chem. 2003. Vol. 51. N26. Pp. 3560-3563.

30. Редико Е. Анализ и стандартизация полифенольного комплекса листьев и жома плодов черной смородины: автореф. дис. ... канд. фарм. наук. М., 2009. 24 с.

31. Харламова О.А., Кафка Б.В. Натуральные пищевые красители. Пищевая промышленность (Качество и ассортимент). М., 1979. $191 \mathrm{c.}$

32. Matsumoto H., Inaba H., Kishi M., Tominaga S., Hirayama M., Tsuda T. Orally administered delphinidin 3-rutinoside and cyanidin 3-rutinoside are directly absorbed in rats and humans and appear in the blood as the intact forms // J. Agric. Food Chem. 2001. N49. Pp. 1546-1551.

33. ГОСТ Р 53773-2010 Продукция соковая. Методы определения антоцианинов.

34. Jelena J. Vulic, Vesna T. Tumbas, SlaCana M. Savatovic, Sonja M. Dilas,Gordana S. Cetkovic, Jasna M. Canadanovic-Brunet Polyphenolic content and antioxidant activity of the four berry fruits pomance extracts // University of Novi Sad, Faculty of Technology, Bulevar cara Lazara 1, 21000 Novi Sad. Serbia, 2011. Vol. 42. Pp. 271-279.

35. Kahkonen M.P., Heinamaki J., Ollilainen V., Heinonen M. Berry anthocyanins: isolation, identification and antioxidant activities // Sci. Food Agric. 2003. N83. Pp. 1403-1411.

36. Cody V., Middleton E., Harborne J.B. Plant flavonoides in biology and medicine. New-York, 1998. Pp. 87-103. 
37. Kowaleryk E., Krzensinski P., Fijalkowski P. et. al. The use of cardiovascular diseases // Pol. Merkuriusz Lek. 2009. Vol. 19. N109. Pp. 108-110.

38. Head K.A. Natural therapies for ocular disorders, part one: diseases of the retina // Altern. Med. Rev. 1999. N4. Pp. 342-359.

39. Head, K.A. Natural therapies for ocular disorders, part two: cataracts and glaucoma // Altern. Med. Rev. 2001. N6. Pp. 141-166.

40. Decker E.A. Phenolics: prooxidants or antioxidants? // Nutr. Rev. 1997. Vol. 55. Pp. 396-407.

41. Patent Application 20130115174 (US). Transmucosal composition containing anthocyanins for alleviating a visual discomfort / Lepelletier Y., Hadj-slimane R., Hadl-slimane T. 2013.

42. Дейнека В.И., Григорьев А.М., Дейнека Л.А., Шапошник Е.И., Староверов В.М. Исследование антоцианов черники в плодах и препаратах на ее основе методом ВЭЖХ // Заводская лаборатория. Диагностика материалов. 2006. №3. Т. 72.

43. Скурихин И.М. Химический состав пищевых продуктов: Книга 1. Справочные таблицы содержания основных пищевых веществ и энергетической ценности пищевых продуктов. М., 1987. 224 с.

44. Ефремов А.А., Макарова Л.Г., Шаталина Н.В., Первышина Г.Г. Минеральные вещества - основа снижения антропогенного воздействия окружающей среды на организм человека // Химия растительного сырья. 2002. №3. C. $65-68$.

45. Демина Л.Н., Паршикова В.Н., Степень Р.А. Минеральный состав водных экстрактов листьев Betula Pendula Roth, Rubes Nigrum L. // Химия растительного сырья. 2003. №4. C. 57-60.

46. Тихонова О.А. Самоплодность новых сортов черной смородины в условиях Северо-Запада России // ГНУ ВНИИ растениеводства им. Н.И.Вавилова. СПб., 2008.

47. Забелина, Л.Н. Адаптивный потенциал новых сортов смородины черной в низкогорье Алтая // Отдел горного садоводства НИИСС им. М.А.Лисавенко. Горно-Алтайск, 2008.

48. Астахов А.И., Каньшина М.В., Зуева Л.И. Адаптивный потенциал новых сортов черной смородины // Проблемы агроэкологии и адаптивность сортов в современном садоводстве России: материалы конференции. Брянск, 2008.

49. Седов Е.Н., Голяева О.Д., Джигадло Е.Н. Лучшие сорта плодовых и ягодных культур Всероссийского научноисследовательского института селекции плодовых культур: справ. издание. Орел, 2005. 124 с.

50. Кузнецова А.А., Петрова С.Н. Антиокислительные свойства экстракта листьев черной смородины // Известия вузов. Прикладная химия и биотехнология. Иркутск, 2012. №2(3). С. 146-147.

51. Williamson G., Manach C. Bioavailability and bioefficacy of polyphenols in humans. II. Review of 93 intervention studies // Am. J. Clin. Nutr. 2005. N81. Pp. 243-255.

Поступило в редакциюю 18 декабря 20132. После переработки 27 декабря 2013 г. 
Petrova S.N., Kuznecova A.A. COMPOSITION OF FRUITS AND LEAVES OF BLACK CURRANT RIBES NIGRUM (REVIEW)

Ivanovo State University of Chemical Technology, Ivanovo, 153000, (Russia), e-mail: laki@isuct.ru

The review of data on a chemical composition, biological activity of substances blackcurrant Ribes nigrum. The presence of biologically active substances in fruits and leaves of black currant defines prospect of its use as a raw material for the production of biologically active additives and food dyes. It is actual to selection work on breeding new varieties of black currants, which will increase the capacity of processing enterprises.

Keywords: black currant, biologically active substances, phenolic compounds, anthocyanins, antioxidant activity.

\section{References}

1. Dejneka L.A., Shaposhnik E.I., Gostishhev D.A., Dejneka V.I., Sorokopudov V.N. Sorbcionnye $i$ hromatograficheskie processy, 2009, vol. 9, issue 4, pp. 529-536. (in Russ.)

2. Brennan R.M., Janick J., Moore J.N. Fruit Breeding, vol. II: Vine and Small Fruits Crops. John Wiley and Sons. Inc. New York, 1996, pp. 191-295.

3. Barney D.L., Hummer K. E. Haworth Press,. Binghamptom, NY, 2005.

4. Shaposhnik E.I., Sorokopudov V.N., Jazykova V.V., Kartushinskij V.V., Tregubov A.V. Nauchnye vedomosti. Se-rija Estestvennye nauki, 2010, no. 15(86), issue 12, pp. 118-124. (in Russ.)

5. Shaposhnik E.I. Biologicheskie $i$ biohimicheskie osobennosti plodov rastenij roda Ribes pri introdukcii $v$ Belgorodskoj oblasti: avtoref. dis. kand. biologicheskih nauk. [Biological and biochemical characteristics of fruit plants of the genus Ribes when introduced in the Belgorod region: dissertation of the candidate of biological sciences]. Belgorod, 2009, 200 p. (in Russ.)

6. Makarkina M.A., Janchuk T.V. 165 let GNU VNIISPK Rossel'hozakademii. Sovremennoe sadovodstvo. Genetika. Selekcija. Sortoizuchenie, 2010, no. 2, pp. 9-12. (in Russ.)

7. Mjasishheva N.V., Artemova E.N. Tehnika i tehnologija pishhevyh proizvodstv, 2013, no. 3. (in Russ.)

8. Poznjakovskij V.M., Plotnikova T.V., Larina T.V., Elizarova L.G. Jekspertiza svezhih plodov i ovoshhej. Kachestvo $i$ bezopasnost': uchebno-spravochnoe posobie. [Expertise of fresh fruits and vegetables. Cooperation and Security: Training and Reference Manual]. Novosibirsk, 2005, 302 p. (in Russ.)

9. Dale A. HortTechnjlogy, 2000, vol. 10, no. 3, pp. 548-554.

10. Strel'cina S.A., Tihonova O.A. Agrarnaja Rossija, 2010, no. 1, pp. 1-16. (in Russ.)

11. Chernobrovina A.G. Fermentativnyj gidrolizat chernoj smorodiny, ego biohimicheskaja harakteristika i primenenie pri poluchenii pishhevyh produktov: dis. kand. him. nauk. [Enzymatic hydrolyzate of black currant, its biochemical characterization and application in the preparation of food: dissertation of the candidate of chemical sciences]. Moscow, 2008, 211 p. (in Russ.)

12. Balakirev G.V. Polnaja jenciklopedija. Lekarstvennye rastenija v narodnoj medicine. [Complete Encyclopedia. Medicinal plants in folk medicine]. Moscow, 2006, 960 p. (in Russ.)

13. Chub V.V. Rost i razvitie rastenij. Moscow, 2003. (in Russ.)

14. Kazakov I.V. Sovremennoe sostojanie kul'tur smorodiny i kryzhovnika: Sb. nauchn. tr. [The current state of cultures currants and gooseberries: Collection of scientific papers]. Michurinsk-Naukograd, 2007, pp. 81-90. (in Russ.)

15. Zhbanova E.V. Agrarnaja Rossija, 2012, no. 1, pp. 10-13. (in Russ.)

16. Vagiri M. Black currant (Ribes nigrum L.) - An insight into the crop: A synopsis of a PhD study. Swedish University of Agricultural Sciences, 2012, 58 p.

17. Stukalov N.V., Trunov Ju.V. VESTNIK MichGAU, 2011, no. 1, vol. 1, pp. 38-41. (in Russ.)

18. MR 2.3.1.2432-08. Normy fiziologicheskih potrebnostej $v$ jenergii i pishhevyh veshhestvah dlja razlichny grupp naselenija Rossijskoj Federacii. [Methodical Recommendations 2.3.1.2432-08. Norms physiological needs for energy and nutrients for different groups of the population of the Russian Federation]. 18.12.2008. (in Russ.)

19. Davydova V.R., Vyhovanec T.A. Novitni tehnologï ozdorovchih produktiv harchuvannja HHI stolittjas: Mizhnarodna naukovo-praktichna konferencija, 21 zhovtnja 2010. [The latest technology health food stolittyas XXI: International Scientific Conference, October 21, 2010]. Kharkov, 2010, pp. 225-226. (in Ukr.)

20. Tengerekova G.G., Nakvasina E.I., Agaeva O.P., Kuznecova O.V., Ljashevskaja N.V. Materialy mezhdun. konf. «Bioraznoobrazie, problemyjekologii Gornogo Altaja i sopredel'nyh regionov: nastojashhee, proshloe, budushhee». [Proceedings of the International Conference on "Biodiversity, problemyekologii of the Altai Mountains and adjacent regions: past, present and future"]. Gorno-Altaisk, 2008, vol. II, pp. 187-180. (in Russ.)

21. Chrzanowski G., Sempruch C., Sprawka I. Electronic Journal of Polish Agricultural Universities, 2007, vol. 10, no. 4.

22. Makarov V.N., Vlazneva L.N., Zhbanova E.V., Denisova A.V., Abyzov V.V., Gljadelkina A.S., Zacepina I.V. Hranenie i pererabotka sel'hozsyr'ja, 2011, no. 2, pp. 44-52. (in Russ.)

23. Travnikova E.V. Smorodina. [Currant]. Moscow, 1996, 208 p. (in Russ.)

24. Ekimov A.A., Lomkova E.A. Sbornik tezisov nauchnoj konferencii, posvjashhennoj 300-letiju so dnja rozhdenija M.V. Lomonosova. [Collection of abstracts of scientific conference devoted to the 300th anniversary of M.V. Lomonosov]. Saint Petersburg, 2011, pp. 14-17. (in Russ.)

25. Chrzanowski, G. C. Sempruch, I. Electronic Journal of Polish Agricultural Universities, 2007, no. 4, 6 p.

*Corresponding author. 
26. Makarevich A.M., Shutova A.G., Spiridovich E.V., Reshetnikov V.N. GNU «Central'nyj botanicheskij sad NAN Belarusi». Minsk, 2010, vol. 4, issue 2, 11 p. (in Russ.)

27. Nakaishi H., Matsumoto H., Tominaga S., Hirayama M. Altern. Med. Rev, 2000, vol. 5, pp. 553-562.

28. Novruzov E.N. Pigments of the reproductive organs of plants and their value. Baku, 2010, $308 \mathrm{p}$.

29. Matsumoto H., Nakamura Y., Tachibanaki S., Kawamura S., Hirayama M. J. Agric. Food Chem, 2003, vol. 51, no. 26, pp. 3560-3563.

30. Rediko E. Analiz i standartizacija polifenol'nogo kompleksa list'ev i zhoma plodov chernoj smorodiny: avtoref. dis. ...kandidata farmacevticheskih nauk. [Analysis and standardization of polyphenol complex leaves and fruit pulp blackcurrant: dissertation of the candidate of pharmaceutical sciences]. Moscow, 2009, 24 p. (in Russ.)

31. Harlamova O.A. Kafka B.V. Natural'nye pishhevye krasiteli. Pishhevaja promyshlennost' (Kachestvo i assortiment). [Natural food colorings. Food and Related Products (Quality and range)]. Moscow, 1979, 191 p. (in Russ.)

32. Matsumoto H., Inaba H., Kishi M., Tominaga S., Hirayama M., Tsuda T. J Agric Food Chem, 2001, no. 49, pp. $1546-1551$.

33. GOST R 53773-2010 Produkcija sokovaja. Metody opredelenija antocianinov. [State Standart 53773-2010 Products juices. Methods for determination of anthocyanins]. (in Russ.)

34. Jelena J. Vulic, Vesna T. Tumbas, SlaCana M. Savatovic, Sonja M. Dilas,Gordana S. Cetkovic, Jasna M. University of Novi Sad, Faculty of Technology, Bulevar cara Lazara 1, 21000 Novi Sad. Serbia, 2011, vol. 42, pp. 271-279.

35. Kahkonen M.P., Heinamaki J., Ollilainen V., Heinonen M. Sci Food Agric, 2003, no. 83, pp. 1403-1411.

36. Cody V., Middleton E., Harborne JB, editors. Plant flavonoides in biology and medicine. New-York, 1998, pp. 87-103.

37. Kowaleryk E., Krzensinski P., Fijalkowski P. et. al. Pol. Merkuriusz Lek, 2009, vol. 19, no. 109, pp. 108-110.

38. Head K.A. Altern. Med. Rev, 1999, no. 4, pp. 342-359.

39. Head, K.A. Altern. Med. Rev, 2001, no. 6, pp. 141-166.

40. Decker E.A. Nutr. Rev, 1997, vol. 55, pp. 396-407.

41. Patent Application 20130115174 (US). 2013.

42. Dejneka V.I., Grigor'ev A.M., Dejneka L.A., Shaposhnik E.I., Staroverov V.M. Zavodskaja laboratorija. Diagnostika materialov, 2006, no. 3, vol. 72. (in Russ.)

43. Skurihin I. M. Himicheskij sostav pishhevyh produktov: Kniga 1: Spravochnye tablicy soderzhanija osnov-nyh pishhevyh veshhestv i jenergeticheskoj cennosti pishhevyh produktov - 2-e izd., pererab. i dop. [Chemical composition of foods: Book 1: Reference tables of content-governmental foundations pischevyhveschestv and energy value of food - 2nd edition, revised and enlarged]. Moscow, 1987. 224 p. (in Russ.)

44. Efremov A.A., Makarova L.G., Shatalina N.V., Pervyshina G.G. Himija rastitel'nogo syr'ja, 2002, no. 3, pp. 65-68. (in Russ.)

45. Demina L.N., Parshikova V.N., Stepen' R.A. Himija rastitel'nogo syr'ja, 2003, no. 4, pp. 57-60. (in Russ.)

46. Tihonova O.A. Samoplodnost' novyh sortov chernoj smorodiny v uslovijah Severo-Zapada Rossii. [Selffertility of new varieties of black currant in the North-West of Russia.]. St. Petersburg, 2008. (in Russ.)

47. Zabelina, L.N. Adaptivnyj potencial novyh sortov smorodiny chernoj v nizkogor'e Altaja. [Adaptive potential of new varieties of black currants in low Altai]. Gorno-Altajsk, 2008. (in Russ.)

48. Astahov A.I., Kan'shina M.V., Zueva L.I. Materialy konferencii «Problemy agrojekologii i adaptivnost' sortov v sovremennom sadovodstve Rossii». [Proceedings of the conference "Problems of Agroecology and adaptability of varieties in modern horticulture Russia"]. Brjansk, 2008. (in Russ.)

49. Sedov E.N., Goljaeva O.D., Dzhigadlo E.N. Luchshie sorta plodovyh i jagodnyh kul'tur Vserossijskogo nauchnoissledovatel'skogo instituta selekcii plodovyh kul'tur: sprav. izdanie. [The best varieties of fruits and berries AllRussian Research Institute of Horticultural Crops Selection: reference book]. Orel, 2005, 124 p. (in Russ.)

50. Kuznecova A.A., Petrova S.N. Izvestija vuzov. Prikladnaja himija i biotehnologija, Irkutsk, 2012, no. 2(3), pp. 146147. (in Russ.)

51. Williamson G., Manach C. Review of 93 intervention studies. Am J Clin Nutr, 2005, no. 81, pp. 243-255. 